\title{
The impacts of lead recycling activities to human health and environment in Dong Mai craft village, Hung Yen, Vietnam
}

\author{
Những ảnh hương của hoạt động tái chế chì tới sức khỏe và môi trương tại làng \\ nghề Đông Mai, Hưng Yên, Việt Nam \\ Research article
}

Phan, Thi Phuong ${ }^{1}$; Pham, Thi Thao Trang ${ }^{1}$; Nguyen, Khanh Linh ${ }^{1}$; Nguyen, Thi Kim Oanh ${ }^{1}$; Ha, Thi Thu Thuy ${ }^{1}$; Nguyen, Kieu Bang Tam ${ }^{1}$; Chu, Thi Thu Ha ${ }^{2 *}$

${ }^{1}$ Hanoi University of Science, 334 Nguyen Trai, Hanoi, Vietnam; ${ }^{2}$ Institute of Ecology and Biological Resources, Vietnam Academy of Science and Technology, 18 Hoang Quoc Viet, Cau Giay, Hanoi, Vietnam

\begin{abstract}
Lead $(\mathrm{Pb})$ recycling activities in Dong Mai village, Chi Dao commune, Van Lam district, Hung Yen province have been taking place for more than 30 years. The development of recycling activities contributed to the improvement of the local economics. However, along with economic development, Dong Mai craft village is facing to serious pollution. Soil, air and water polluted by lead $(\mathrm{Pb})$ caused food containing $\mathrm{Pb}$ at higher levels than allowed limit from 20 to 40 times. The pollution had the bad effect on human health in this village. The investigation results showed that $100 \%$ of employee who participated on melting lead and $63.5 \%$ of local children were poisoned by $\mathrm{Pb}$. Besides, the local people got diseases relating to skin, eyes, etc. This situation requires the provincial authorities to find immediate solutions to reduce the impacts of $\mathrm{Pb}$ recycling activities to environment and human.
\end{abstract}

Hoạt động tái chế chì của thôn Đông Mai, xã Chỉ Đạo, huyện Văn Lâm, tỉnh Hung Yên đã diễn ra hơn 30 năm nay. Sự phát triển của nghề tái chế đã làm góp phần cải thiện kinh tế của địa phưong. Tuy nhiên, cùng với sự phát triển kinh tế, làng nghề Đông Mai đã và đang đối mặt với ô nhiếm môi trương nghiêm trọng. Môi truờng đất, nước không khi bi ô nhiếm bởi chì (Pb) dẫn đến thực phẩm nhiếm chì ở hàm lượng cao hơn múc cho phép tù 20-40 lần. Sự ô nhiếm gây ra nhũng ảnh huởng xấu tới sức khỏe của người dân làng nghề. Kết quả điều tra cho thấy $100 \%$ công nhân tham gia nấu chì và $63.5 \%$ trẻ em địa phương bị nhiễm độc chì. Bên cạnh đó, người dân địa phương còn bị mắc của các loại bệnh ngoài da, bệnh về mắt, .... Tình trạng này đòi hỏi chính quyền địa phuơng phải tìm ra giải pháp khẩn cấp để giảm thiểu tác động của nhưng hoạt động tái chế chi tới môi truờng và con người.

Keywords: lead recycling, lead level blood, human health, pollution, contamination

\section{Introduction}

Dong Mai craft village, Chi Dao commune, Van Lam district, Hung Yen province is located in northern Vietnam and it has a population of about 2.600 people (637 families).

In 1970s, when the traditional business lost the market, the residents in Dong Mai craft village converted to lead recycle from fail batteries of vehicles such as motorcycle, car, etc. During $1987 \mathrm{~s}$, the $\mathrm{Pb}$ recycle activities was most developed. Each day, the local people treated tons of lead and earned from 90,000-350,000 VND/capita/day, comparing with benefit from agriculture of about 200,000 VND/capita/crop. Thus, the benefit from recycling activities was tens times higher than the one from agriculture. In 2000s, there were about 200 households in the village being responsible or recycling more than 1000 tons of waste per year. The batteries were extracted to collect lead $(\mathrm{Pb})$ inside. Then $\mathrm{Pb}$ was melted down and sold. Most of the recycling activities including the melting process is performed by using simple manual methods at home or near paddy fields. 


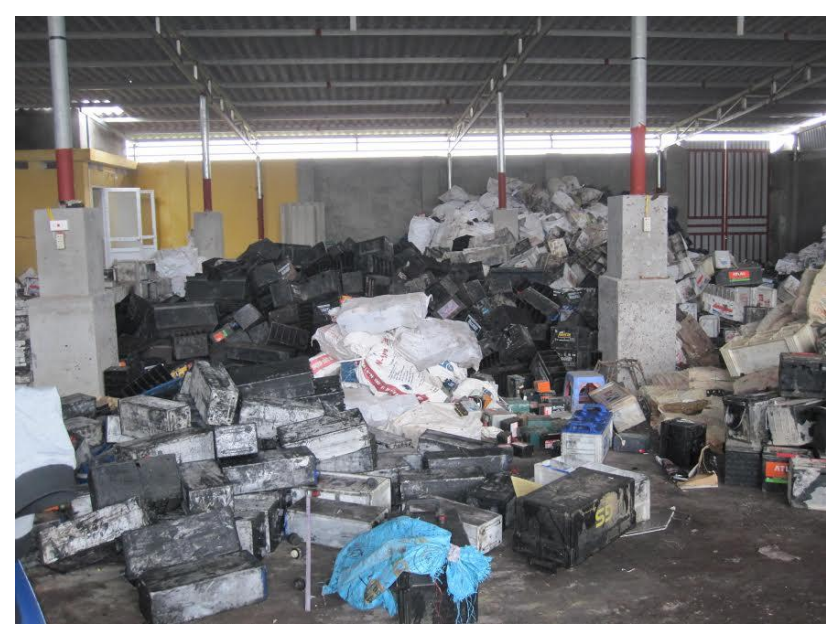

Figure 1. The fail batteries are stored in a firm at Dong Mai craft village

Along with the rapid economic development of Dong Mai craft village, $\mathrm{Pb}$ recycling activities led to bad effects on environment. Local people focused merely on the economic development while they ignored the effect on environment and on the human health due to the shortage of modern technology and equipment as well as the long term plan supported from provincial government. There are two main sources of $\mathrm{Pb}$ polluting environment, they are lead dust primarily from melting lead and from extracted batteries. These particles of $\mathrm{Pb}$ step by step are accumulated in the environment and cause soil, water and air pollution. The agricultural plants grown in contaminated soil and water that accumulate $\mathrm{Pb}$ and other heavy metals cause food contaminated.

Besides the damage to the environment, $\mathrm{Pb}$ recycling activites have significant impact on the humans health. People can be exposed to lead through occupational and environmental sources. They inhale the lead particles that generated by burning materials containing lead. Moreover, ingestion of lead -contaminated foods, water is also the route of poisoning lead for human. Lead poisoning has extremely bad effect for human health. Some initial signs of lead poisoning are digestive upset, vomiting, diarrhea, abdominal pain, decreased red blood cell by interfering with the synthesis of hemoglobin, decreased blood to the kidneys causing kidney failure. Half-life for lead emissions from kidney is 7 years, from bone is 32 years (Nies and Silver, 1995).

Young children that are vulnerable to the toxic effects of lead and can suffer profoundly and permanently adverse health effects, especially, the disordered development of the brain and nervous system. Young children are particularly vulnerable because they absorb 4-5 times as much ingested lead as adults from a given source. At high levels of exposure, lead attacks the brain and central nervous system to cause coma, convulsions and even death. According to the Centers for Disease Control and Prevetion (CDC), American Academy of Pediatrics (AAP) the safety lead level blood threshold for children is lower than $5 \mu \mathrm{g} / \mathrm{dL}$, for pregnant is smaller than $10 \mu \mathrm{g} / \mathrm{dL}$, and strong people is upper $25 \mu \mathrm{g} / \mathrm{dL}$. Lead also causes long-term harm in adults, including increased risk of high blood pressure and kidney damage. Exposure of pregnant women to high levels of lead can cause miscarriage, stillbirth, premature birth and low birth weight, as well as minor malformations.

In 2012, the Institute of Occupational and Environmental Hygiene (MOH) and the University of Washington (USA) chose 109 children under 10 years old in Dong Mai to test lead level blood. Result showed that $100 \%$ of children had blood lead levels exceeding the allowable limits. Specifically, 15 children were in dangerous threshold (65 $\mu \mathrm{g} / \mathrm{dL}) ; 17$ children were at alarming rate $(45-65 \mu \mathrm{g} / \mathrm{dL})$; 70 children were at too high levels $(25-44 \mu \mathrm{g} / \mathrm{dL})$ and 7 children infected at concern levels $(10-19 \mu \mathrm{g} / \mathrm{dL})$.

The seriously environmental degradation and the bad influence to human health especially children's health in Dong Mai craft village require concern from local authorities and scientists.

\section{Objective and methods}

\subsection{Objective}

The objective of this report is investigation in recycling activities at Dong Mai craft village and assessment of their effect on environment as well as on human health.

\subsection{Methods}

\subsubsection{Collecting data method}

The information was collected from reports of Chi Dao commune office and interviewees that participated in the $\mathrm{Pb}$ recycling activities in Dong Mai craft village.

\subsubsection{Collecting samples}

Soil and wastewater samples near the $\mathrm{Pb}$ recycling smelters were collected, pretreated and analyzed contents of lead and cadmium.

\subsubsection{Analysis method}

The contents of $\mathrm{Pb}$ and $\mathrm{Cd}$ in soil and wastewater were measured by using methods: SMEWW 3125:2012, SMEWW 3111B:2012 \& EPA 3051:2007.

\section{Results}

\subsection{Impacts to the environment}

\subsubsection{Soil environment}

$\mathrm{Pb}$ contaminates soil by negligence or purposefulness. In the first way, $\mathrm{Pb}$ after being extracted is put on the ground, then moved to melting place. Small parts of lead dust stay in ground and leach to upper soil layer, it causes lead contaminated soils. In the latter case, $\mathrm{Pb}$ also contaminates soil by purposeful action of local people, for example, they crush lead ashes, then bury it into the soil without any treatment. 
The results of analysing soil samples taken from the paddy field near $\mathrm{Pb}$ recycling zones showed that the contents of $\mathrm{Pb}$ in the soil ranged from 292- $2729 \mathrm{mg} \cdot \mathrm{kg}^{-1}, \mathrm{DW}$ and the cadmium from 0.31 to $0.93 \mathrm{mg} \cdot \mathrm{kg}^{-1}$, DW. These values of $\mathrm{Pb}$ were higher than the allowable limit $\left(70 \mathrm{mg} \cdot \mathrm{kg}^{-1}\right)$ from 4 to 40 times given in the National technical regulation on the allowable limits of heavy metals in the soils (QCVN $03: 2008 / \mathrm{BTNMT})$. The content of cadmium is under allowable limit $\left(2 \mathrm{mg} \cdot \mathrm{kg}^{-1}\right)$.

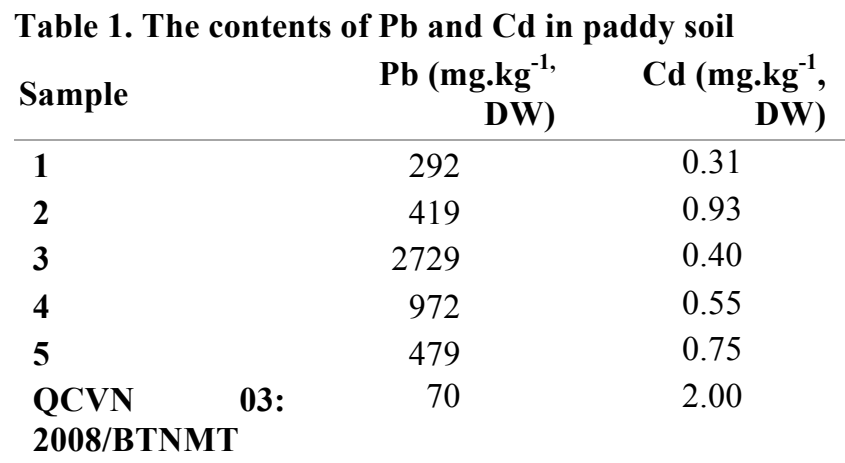

\subsubsection{Water environment}

Based on the structure of batteries, they contain not only lead electrodes but also acid solution. When the workers extract the batteries, the acid solution runs out. In some cases, such as it rains, this solution associates with the rainwater then goes to the surface water body like river, canal, pond; and in the long term, it can leach to the ground water. The mixture of acid and rain water can contain lead dust from lead recycling activities that makes the water sources polluted by $\mathrm{Pb}$ as well.

In the past, $\mathrm{Pb}$ recycling activity was at small scale in household, the wastewater was discharged directly to the river and pond together with domestic wastewater, without any treatment. Since 2015, some people who had their own firm established association and spent the common equipments such as treatment tank and furnace. Then they used limestone for neutralization of $\mathrm{pH}$ in wastewater but cannot eliminate $\mathrm{Pb}$, therefore, the wastewater is still contaminated by $\mathrm{Pb}$.

When being interviewed in November 2015, almost employers said that each firm had primary treatment tank that used lime to neutralize acid, and then the wastewater wass led to treatment tank of whole company zone. However, some workers/employees at the firm said that the wastewater was discharged to the treatment tank without any primary treatment.

We took the wastewater samples from the treatment tank at firms, whole company zone as well as the ditches around the company. The result of $\mathrm{Pb}$ and $\mathrm{Cd}$ analysis is shown in table 2 .

The analysis result in table 2 indicated that the wastewater samples contained $\mathrm{Pb}$ concentration from 2.33 to $2.5 \mathrm{mg} / 1$, while the permission level of $\mathrm{Pb}$ is $0.5 \mathrm{mg} / \mathrm{l}$ for in industrial wastewater discharged into receiving facilities not using for sources of domestic water supply, according to $\mathrm{Na}$ tional Technical Regulation on Industrial Wastewater
(QCVN 40: 2011/BTNMT). It can be said that the levels of $\mathrm{Pb}$ in wastewater in Dong Mai craft village were higher than permission limit from 4- 5 times.

\section{Table 2. The values of $\mathrm{Pb}$ and $\mathrm{pH}$ in wastewater}

\begin{tabular}{lrc} 
Sample & Pb (mg/l) & pH \\
\hline $\mathbf{1}$ & 2.42 & 6.95 \\
$\mathbf{2}$ & 2.33 & 1.4 \\
$\mathbf{3}$ & 2.35 & 0.87 \\
$\mathbf{4}$ & 2.50 & 0.96 \\
QCVN 40: & 0.50 & $5.5-9$ \\
$\mathbf{2 0 1 1 / B T N M T}$ & &
\end{tabular}

As well as other heavy metals, $\mathrm{Pb}$ existing in the environment is greatly influenced by $\mathrm{pH}$. $\mathrm{Pb}$ is generally in three main forms: dissolved, deposited in sediments and accumulated in organisms. In the dissolved form, $\mathrm{Pb}$ is commonly found in domestic wastewater, especially industrial wastewater. When the $\mathrm{pH}$ of the medium de-creases the solubility of $\mathrm{Pb}$ increases.

The $\mathrm{pH}$ values of wastewater samples collected were from 0.87 to 6.95. In comparison to the QCVN 40: 2011/BTNMT, only 1 wastewater sample had the $\mathrm{pH}$ value in the permission range (Table 2), the other samples had very low $\mathrm{pH}$ values. That means the wastewater was not treated to neutralize acid.

\subsubsection{Air environment}

In addition to the water and soil contamination in Dong Mai craft village, the air is also polluted. This pollution is caused mainly by lead melting and lead transporting without any cover. In 2013, Centre for Environment and Community Development (CECoD) in collaboration with Blacksmith Institute (USA) held a survey to measure levels of lead in soil by XRF analyzer Model $\alpha 4000$ in the village streets, the school districts and 539 village households in Dong Mai. Survey results showed that the lead contents were in the range from 400-5,000 ppm (by US standards for lead content in soil for residential areas is $400 \mathrm{ppm}$ ).

Table 3. The frequency and amount of $\mathrm{Pb}$ melting

\begin{tabular}{ccc} 
Owner & $\begin{array}{c}\text { Frequency } \\
\text { (batches/ month) }\end{array}$ & $\begin{array}{c}\text { Amount } \\
\text { (tonnes/batch) }\end{array}$ \\
\hline $\mathbf{1}$ & $15-20$ & $9-10$ \\
$\mathbf{2}$ & $15-17$ & $8-9$ \\
$\mathbf{3}$ & $7-10$ & $5-8$ \\
$\mathbf{4}$ & $4-5$ & $0.7-1$ \\
$\mathbf{5}$ & $2-3$ & 5
\end{tabular}

The air environment is most polluted when lead is melted. Because the furnaces are quite near resident zone, just about $1 \mathrm{~km}$, and the frequency of $\mathrm{Pb}$ melting performance of households and firms is every night at the furnaces. Every month, each owner of household/firm had to register his/her plan of melting $\mathrm{Pb}$ with the manager of furnaces. Number of $\mathrm{Pb}$ melting batches of each household/firm were from 2 to 20 per month, it means each household/firm 
used the furnaces from 2 to 20 nights per month. The amount of $\mathrm{Pb}$ production is very different between households and firms, from 0.7 to 9 tonnes $\mathrm{Pb}$ per night (Table 3). It can be calculated that total of $\mathrm{Pb}$ production was from 2.8 to 200 tonnes per month per household or firm.

In the past, hundreds of households participated in $\mathrm{Pb}$ recycling. Nowadays, the number is reduced, with about 50 households and firms still continue this traditional occupation. However, the scale is bigger requiring more workers involving in this activities.

\subsection{Impacts to human health}

The human health is impact by inhalation in contaminated air and ingesting the $\mathrm{Pb}$ accumulated foods.

In the first case, the workers in Dong Mai craft village destroy the wasted batteries mostly by hands for lead extraction with $\mathrm{Pb}$ dust around them. They are not equipped enough safe working clothing and have to breath in $\mathrm{Pb}$ polluted air. This increases the ability of susceptible getting diseases. In addition, $\mathrm{Pb}$ dust also affects the local people who do not participate in $\mathrm{Pb}$ recycling activities because they live near the $\mathrm{Pb}$ recycling zone.

In the latter case, the farmers use water in river, pond for irrigation, the plants uptake $\mathrm{Pb}$ and other heavy metals in the water, it causes food contaminated.

The plants growing in lead contaminated soil and water also contained the amount of lead exceed the allowable limitation. The study of Dang Thi An et al. (2008) at Chi Dao commune showed that the amount of lead accumulated in rice from $1.9 \mathrm{mg} \cdot \mathrm{kg}^{-1}$, DW to $4.2 \mathrm{mg} \cdot \mathrm{kg}^{-1}$, DW, while the permission level of National technical regulation on the limits of heavy metals contamination in rice (QCVN 8-2: 2011/ $\mathrm{BYT}$ ) with $\mathrm{Pb}$ is $0.2 \mathrm{mg} \cdot \mathrm{kg}^{-1}$ and $\mathrm{Cd}$ is $0.4 \mathrm{mg} \cdot \mathrm{kg}^{-1}$.

Table 4. Contents of $\mathrm{Pb}$ and $\mathrm{Cd}$ in rice

\begin{tabular}{|c|c|c|}
\hline No. & $\begin{array}{l}\text { Pb (mg.kg- } \\
1, \mathrm{DW})\end{array}$ & $\begin{array}{l}\text { Cd (mg.kg }{ }^{-1} \text {, } \\
\text { DW) }\end{array}$ \\
\hline 1 & 3.8 & 0.17 \\
\hline 2 & 2.2 & 0.05 \\
\hline 3 & 3.5 & 0.06 \\
\hline $\begin{array}{c}\text { QCVN 8-2: 2011/ } \\
\text { BYT }\end{array}$ & 0.2 & 0.4 \\
\hline
\end{tabular}

In our research, we tested the content of $\mathrm{Pb}$ and $\mathrm{Cd}$ in 3 rice samples collected near the $\mathrm{Pb}$ recycling zone in Dong Mai craft village. Table 4 showed that the investigated rice samples contained from 2.2 to $3.8 \mathrm{mg} . \mathrm{kg}^{-1}$, DW and from 0.05 to $0.17 \mathrm{mg} \cdot \mathrm{kg}^{-1}$, DW, respectively with $\mathrm{Pb}$ and $\mathrm{Cd}$ contents. Comparing these values with allowable level of Ministry of Health, the contents of $\mathrm{Pb}$ in rice were much higher and contents of $\mathrm{Cd}$ were under limit values.

According to Nguyen Dang Anh, deputy director of the Natural Resources and Environmental Department of Van Lam District, blood test results of local residents, particularly children in the village, revealed that percentages of lead were higher in these children than what is allowed.
Results from a recent health check of local primary children in Dong Mai village by the Ministry of Health's Institute of Health an Environment have showed that 207 of 355 tested children got lead poisoning, accounting for $65.3 \%$, especially 33 children whose blood lead level were over 70 $\mathrm{mg} / \mathrm{dl}$ need to eliminate urgently. Because of the polluted routes from surrounding such as air, water as well as food, $80 \%$ people in Dong Mai craft village got diseases while $50 \%$ of diseases related to stomach, $30 \%$ were respiratory and eye diseases.

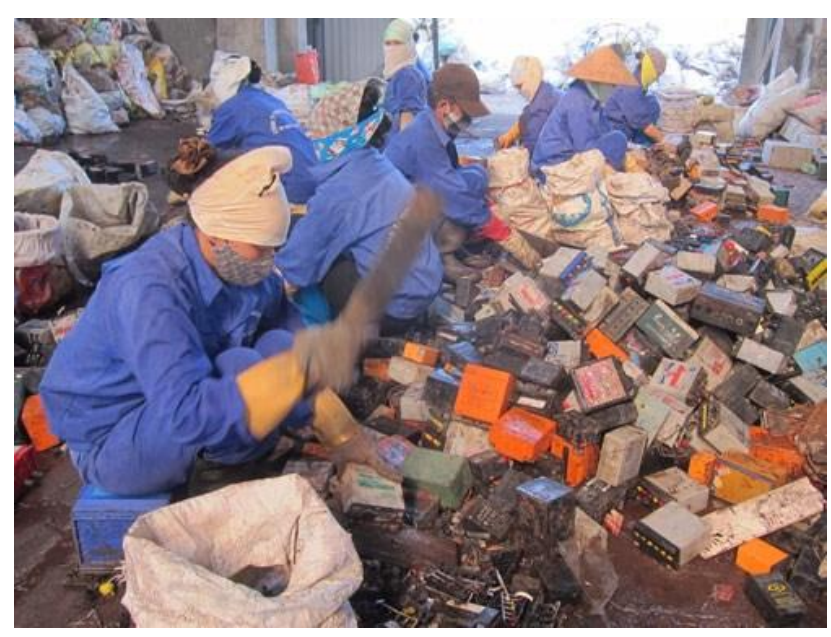

Figure 2. The workers were extracting $P b$ from fail batteries

In the other hand, $100 \%$ workers working at $\mathrm{Pb}$ recycling factories got lead poisoning. $80.77 \%$ workers said that their family members had diseases related to respiration and digestion. Apart from these diseases, we found some seriously cases, for example, a worker at furnace for 20 years was detected heavily poisoned, up to $90 \%$, and he had 2 children that also had high lead level in blood. In case of another worker, his wife got trouble about nervous system and his daughter had high lead level in blood. One owner of $\mathrm{Pb}$ recycling factory who has been working on this job for 35 years had lead concentration in blood at level of $69 \%$, while for his first child the concentration was $28 \%$ and his second child got innate brain disease. From this information that we collected by interview, we can see that the impacts of lead on human health especially children is seriously.

The majority of workers believed that the cause for diseases was from polluted water and soil. The workers thought that $\mathrm{Pb}$ recycling job is not safe for their health, and about $83.33 \%$ workers who were asked said that they were going to find other jobs, which would be not harmful for their health.

\section{Recommendation}

The polluted environment and high rate of diseases in local people in Dong Mai craft village raises an alarm among provincial authorities to find immediate solutions to protect the environment and human health. They should appeal the help form businesses, government to support the fund for curing diseases, especially decreasing lead level in blood of local people, especially children. 
For long term, they need to find out an environmentally friendly method to remediate efficiently the pollution and update technology to prevent the distribution of pollutants to environment.

\section{Conclusions}

The lead recycling activities have been bringing the negative impacts to environment including air, water and soil pollution with $\mathrm{Pb}-\mathrm{a}$ very toxic heavy metal. The $\mathrm{Pb}$ polluted environment caused adverse effect on and human health through inspiration and ingestion. These are extremely dangerous for the local people and next generation with extremely serious diseases such as $\mathrm{Pb}$ blood poisoning, disordered brain development.

Acknowledgement: The authors thank to the financial support from Vietnam Academy of Science and Technology for the research project that has code: VAST07.03/1617.

\section{References}

[1] Bernard A (2008) Cadmium \& its adverse effects on human health. Indian J Med Res. 128(4):557-64.

[2] Chi Dao commune report (2015) The implementation of socio-economic aspects 2015, the directions, missions and solutions in 2016 (In Vietnamese).

[3] Dang Thi An, Tran Quang Tien (2008) Pb-Cd contamination in agricultural soils and in produces in Van Lam, Hung Yen. Vietnam Soil Sicence 29, 56-58 (In Vietnamese).

[4] International Cadmium Association. Cadmium exposure and human health. Retrieved from http://www.cadmium.org/environment/cadmium-exposure-and-human-health.
[5] Ministry of Health (2011) National technical regulation on the limits of heavy metals contamination in food (QCVN 8-2011/BYT) (In Vietnamese).

[6] Ministry of Natural resources and Environment (2008) National technical regulation on the allowable limits of heavy metals in the soils (QCVN 03:2008/ BTNMT) (In Vietnamese).

[7] Ministry of Natural resources and Environment (2011) National Technical Regulation on Industrial Wastewater (QCVN 40:2011/ BTNMT) (In Vietnamese).

[8] Nam Phuong (2015), pollution at craft village. Retrieved from: http://congannghean.vn/phongsu/201501/lang-o-nhiem-chi-thay-ma-so-583355/.

[9] Nies, D. H., and S. Silver 1995. Ion efflux systems involved in bacterial metal resistances. J. Ind. Microbiol. 14:186-199.

[10] Vietnam News (2016) Lead recycling in village threatens local environment, health. Retrieved from http://vietnamnews.vn/society/employment/270460/lead-recycling-in-village-threatens-local-environmenthealth.html\#Sr3TY1cVg67EJj5W.97 (In Vietnamese).

[11] William E. Daniell, Lo Van Tung, Ryan M. Wallace, Deborah J. Havens, Catherine J. Karr, Nguyen Bich Diep, Gerry A. Croteau, Nancy J. Beaudet, and Nguyen Duy Bao (2015) Childhood Lead Exposure from battery Recycling in Vietnam. BioMed Research International, $10 \mathrm{pp}$.

[12] World Health Organization (2016) Lead poisoning and health. Retrieved from http://www.who.int/mediacentre/factsheets/fs379/en/. 